\title{
Determination and Comparative Evaluation of Mineral Content of Honey obtain from Rivers State University, Forestry Arboretum and Port Harcourt Local Market
}

\author{
NNADI, PC \\ Forestry Department, Rivers State University, Port Harcourt. Rivers State, Nigeria \\ Email: picaso1ng@yahoo.com
}

\begin{abstract}
The study was concerned with the comparative study of honey produced from forestry arboretum in Rivers State University and the local market. The objective of this research was to determine and compare the Mineral Content of Honey Obtained from Rivers State University, Forestry Arboretum and the local market Using Atomic Absorption Spectrophotometer (Buck Scientific $210 \mathrm{vp}$ ) after digestion. Five elements were analyzed which include Calcium, Iron, Zinc, Magnesium and Potassium. The results gotten from the forestry arboretum honey are as follows; Calcium $1.14 \pm 0.062 \mathrm{mg} / 100$, Iron $0.32 \pm 0.001 \mathrm{mg} / 100$ Magnesium $5.4 \pm 0.472 \mathrm{mg} / 100$, Zinc $0.12 \pm 0.062 \mathrm{mg} / 100 \mathrm{~g}$ and potassium $470 \pm 47.450 \mathrm{mg} / 100$ while for the local market Calcium is $0.3 \pm 0.0017 \mathrm{mg} / 100 \mathrm{~g}$, Iron $0.4 \pm 0.003 \mathrm{mg} / 100 \mathrm{~g}$, Zinc $0.17 \pm 0.0062 \mathrm{mg} / 100$, magnesium $7.2 \pm 0.260 \mathrm{mg} / 100$, and potassium $12.3 \pm 0.145 \mathrm{mg} / 100$. However Potassium, Calcium and Magnesium were the most abundant samples in the forestry arboretum and this is very important for development of the bones general body formation. A total of fifteen panelist were used to evaluate the honey sensory on a four point scale for different parameters. It was observed that appearance and opagueness has the highest score for samples, 3.43 and 3.42 respectively in forestry arboretum and the local market while texture, viscosity, taste and aroma are not farfetched. The results indicate that qualities of both honey samples are acceptable and both Honey Samples are rich in minerals.
\end{abstract}

DOI: $\underline{\text { https://dx.doi.org/10.4314/jasem.v24i9.17 }}$

Copyright: Copyright (C) 2020 Nnadi. This is an open access article distributed under the Creative Commons Attribution License (CCL), which permits unrestricted use, distribution, and reproduction in any medium, provided the original work is properly cited.

Dates: Received: 10 August 2020; Revised: 16 September 2020; Accepted: 22 September 2020

Keywords: Honey, Plant Diversity, Mineral Content, Forestry arboretum

Honey is a sweet natural product produced by honey bees (Apis mellifera) that collect the nectar from flowers and convert it into a delicious food product that is known to be a more health beneficial nutritional option than plain sugar (Vanhanen et al., 2011). It is mainly composed of fructose and glucose $(65 \%)$ which is easily absorbed by the body (Nnadi et al., 2011) as well as water $(18 \%)$ with minimal protein and lipid contents. (Khalil et al 2001, Silvia et al, 2001). Honey also contain minerals which play important roles in determining honey qualities. The mineral content varies ranging from $0.04 \%$ in pale honey to $0.20 \%$ in darker honeys (Bog danov et al., 2007). The major minerals are gotten from the nectar-producing plants. It has been reported that micro or trace minerals originating from organic or plant sources are important for maintaining human health (Hernadez et al., 2005). Honey has various nutritional, medicinal and properties contributed by its chemical constituents, nevertheless in order to yield medicinal effects, honey should be free of contaminants, there is an increasing interest in the study of honey (Mckee 2003). Honey bees is estimated to forage on plants growing over a largely relatively area and when going from flower to flower, they are also in contact with air, water, soil, branches and leaves. Therefore, honey is the result of a bio-accumulative process that is useful for collecting information about the environment and may be considered as a bio-indicator of environmental pollution (Bratu and Beorgescu 2005). In addition to being nutritive sweetner, research also indicates that honey with its unique composition makes it useful as an antimicrobial agent and antioxidant. Honey also reduces skin inflammation, edema and exudation as well as promotes wound healing, diminishes scar size and stimulates tissue regeneration. It is also evident by research that honey helps to reduce cardiovascular risk factor. No mineral analysis research have been done on the mineral composition of natural honey produced in the forestry department of Rivers State University, Port Harcourt, Nigeria. This research will help to determine the mineral elements composition of honey produced from forestry arboretum in Rivers State University. Port Harcourt. Therefore, the Objective of this Paper is to determine and Compare the Mineral Content of Honey Obtained from Rivers State University, Forestry Arboretum and Port Harcourt Local Market.

\section{MATERIAL AND METHODS}

Study Area: The study was conducted in the arboretum of forestry and environment, Rivers State University, Nkpolu-Oroworukwo situated in latitude $4.51^{\circ} \mathrm{N}$ and longitude $7.01^{\circ} \mathrm{E}$ at an attitude of $233 \mathrm{~m}$ above sea level (Tariah et al., 1999) and local market.

Sample Collection: Freshly harvested honey was collected from the Arboretum of forestry and local 
market. The samples was kept in a container at room temperature and thereafter taken to food and science technology laboratory department of Rivers State University, Port Harcourt for analysis.

Sample Preparation: $1 \mathrm{~g}$ of sample was weight into a previously washed and dried porcelain crucible. It was ignited at $550^{\circ} \mathrm{C}$ for 2 hours in a muffle furnace (model SXL) and it was allowed to cool. $5 \mathrm{ml}$ of concentrated hydrochloric acid was added to the ash in the crucible and diluted with $20 \mathrm{ml}$ of de-ionised water. The content of the crucible was heated on a hot plate until it boiled down to half its volume (about $10 \mathrm{ml}$ ). It was allowed to cool, filtered into a $100 \mathrm{ml}$ volumetric flask using whatman no. 1 filter paper and make up to volume using de-ionized water (A.O.A.C 2005).

Elemental assay using Atomic Absorption spectrophotometer (Buck scientific $210 \mathrm{vp}$ ): Acetylene gas was put on the main switch. The lamp of the elements was put on to be analyzed in the lamp position. Air-acetylene knob was turn on and the fuel supply was switch on to ignite the flame. Standard for each metal was run and the sample digest was aspirated (AOAC, 1990, HC 2002, Downey et al 2005).

The content of the element was calculated using the formular below.

$$
\operatorname{Metal}(\%)=\frac{C \times V}{10^{4} \times \mathrm{SW}}
$$

Where, $\mathrm{C}=$ concentration, ppm; $\mathrm{V}=$ solution volumes and $\mathrm{SW}=$ sample weight

\section{Determination of mineral composition}

Potassium: The Atomic absorption spectrophotometer was allowed to stabilize after mounting the potassium hollow cathode lamp and setting the wave length at $766.5 \mathrm{~nm}$. Potassium standard in the range of 5, 10, 15 and $20 \mathrm{ppm}$ was prepared from the potassium standard stock solutions. The equipment using the standard solution was calibrated to obtain the standard graph. The sample digest was run and the values on the screen displayed was recorded. The potassium content in the sample was calculated using the formular above

Calcium: The AAS was setup using the calcium hollow cathode lamp at wave length of $422.7 \mathrm{~nm}$. The calcium standard in the range of $0.5,1.0,2.0$ and $3.0 \mathrm{ppm}$ was prepared from the calcium standard solution. The equipment using the standard solution was calibrated to obtain the calcium standard graph. The sample digest was run and the values in ppm as displayed on the screen was recorded. Calcium content of the sample was then calculated using the formular above.

Magnesium: The AAS was setup using Magnesium hollow cathode lamp at a wave length of $202.6 \mathrm{~nm}$. Magnesium standard solution of the following concentration of $0.5,1.0,2.0$ and $4.0 \mathrm{ppm}$ was prepared from the standard stock solution.

The equipment was zero using de-ionized water. Magnesium standard was run to obtain the standard plot. The sample digest was run and the values displayed on the screen was also recorded. The magnesium content of the sample was also calculated using the formular as provided.

Iron: The AAS equipment was set up using the iron hollow cathode lamp at wave length of $248.3 \mathrm{~nm}$. The iron standard in the range of 1-4 ppm was prepared using the iron standard stock solution. The standard on the AAS was run to obtain the standard plot. The sample digest was also be aspirated and the displayed values was recorded. The amount of iron was calculated using the formular provided

Zinc: The AAS was setup using Zinc hollow cathode lamp at a wave length of $3336 \mathrm{~nm}$. Zinc standard solution of the following concentration of $0.5,1.0,2.0$ and $4.0 \mathrm{ppm}$ was prepared from the standard stock solution.

The equipment was zero using de-ionized water. Zinc standard was run to obtain the standard plot. The sample digest was run and the values displayed on the screen was also recorded. The zinc content of the sample was also calculated using the formular as provided.

Sensory evaluation: Sensory evaluation of the two honey samples were carried out by 15 panelist for different parameters such as colour, aroma, taste, texture, opagueness and viscosity as described by Iwe (2010) the rating were described as like extremely, like slightly, dislike extremely and dislike slightly.

Statistical Analysis: The data obtained in the study was analyzed statistically using t-test for determining the mineral composition and sensory evaluation.

\section{RESULTS AND DISCUSSION}

The results of the mineral composition of the two honey samples as shown on table 1 , showed significant differences $(p>0.05)$ between the sample for calcium, iron, zinc, magnesium and potassium. Comparing the results of honey gotten from forestry arboretum and local market. Calcium in forestry arboretum $1.4 \pm$ $0.062 \mathrm{mg} / 100 \mathrm{~g}$ while local market $0.3 \pm 0.0017 \mathrm{mg} / \mathrm{g}$ iron in forestry arboretum $0.32+0.0001 \mathrm{mg} / 100 \mathrm{~g}$ while the local market $0.4 \pm 0.003 \mathrm{mgl} 100 \mathrm{~g}$ zinc in forestry arboretum $0.12 \pm 0.077 \mathrm{mg} / 100 \mathrm{~g}$ while the local 
market $0.17 \pm 0.062 \mathrm{mg} / 100 \mathrm{~g}$. Magnesium in Local market is $5.4 \pm 0.472 \mathrm{mg} / 00 \mathrm{~g}$ while Forestry arboretum is $7.2+0.260 \mathrm{mgk} 00 \mathrm{~g}$ potassium in forestry arboretum $470 \pm 47.450 \mathrm{~g} \mathrm{mg} / 100 \mathrm{~g}$ while the local market $12.3 \pm 0.145 \mathrm{mg} / 100 \mathrm{~g}$. The results of study shows that the honey samples analyzed are quite rich in minerals.

Table 1. T-test of mineral compositions of two honey sources (Mean \pm Standard Deviation)

\begin{tabular}{lll} 
Minerals n=2 & Local Market Honey & RSU Forestry Arboretum Honey \\
\hline Calcium & $0.3 \pm 0.0017$ & $1.14 \pm 0.062^{*}$ \\
Iron & $0.4 \pm 0.003$ & $0.32 \pm 0.0001^{\mathrm{ns}}$ \\
Zinc & $0.17 \pm 0.062$ & $0.12 \pm 0.077^{\mathrm{ns}}$ \\
Magnesium & $5.4 \pm 0.472$ & $7.2 \pm 0.260^{*}$ \\
Potassium & $12.3 \pm 0.145$ & $470 \pm 47.450^{*}$ \\
\hline \multicolumn{2}{c}{ *ignificant difference at $P<0.05$, ns-not significant difference at $P>0.05$}
\end{tabular}

\begin{tabular}{lllllll}
\multicolumn{7}{c}{ Table 2: Sensory evaluation } \\
& Like & Like & Dislike & Dislike & Mean of \\
Extremely & Slightly & Extremely & Slightly & Means & Remarks \\
\hline Appearance/Colour & 6 & 8 & 0 & 0 & 3.42 & Accept \\
Texture & 6 & 6 & 2 & 0 & 3.28 & Accept \\
Aroma/Odor & 7 & 2 & 2 & 3 & 2.92 & Accept \\
Taste & 5 & 4 & 2 & 3 & 2.78 & Accept \\
Opaqueness & 6 & 8 & 0 & 0 & 3.42 & Accept \\
Viscosity & 5 & 9 & 0 & 0 & 3.36 & Accept \\
\hline \multicolumn{7}{c}{ Accept if $M>2.5:$ Reject if $M<2.5$} \\
\end{tabular}

Sensory Evaluation: There were no significant differences between the two honey samples, the score gotten from both sample 3.43 and 3.42 for Appearance and opaqueness, 3.6 for viscosity, 3.29 and 3.28 for texture, 2.93 and 2.92 for aroma, and 2.79 and 2.78 for Taste. Appearance and opaqueness had the highest score.

Honey produced by honey bees (Apis mellifera) is one of the oldest traditional medicine known to man for therapeutic and prophylactic uses (Mulu et al 2005, Mboto et al 2009). High amount of Calcium, Magnesium and potassium was obtained from forestry arboretum sample than that of the local market as shown in the table above. From the result obtained, forestry arboretum honey had higher values of magnesium, potassium and Calcium, and this is as a result of different indigenous fruit tree species such as Chrysophyllum albidum which have enormous nutritional values and need to be conserved since they are going into Extinction, (Nnadi and Anyanwu, 2018)and they serve as a source of nectar for the Bees. Higher values of these elements were reported from honey samples from Egypt by Rahed and solfan (2004) and lower values than what was obtained in this study were reported in honey samples from Argentina by cantarelli et al (2008). These minerals among the others are essential for humans and they play an important role on a number of biochemical processes (Garcia et al 2001), the variation of mineral elements in honey samples from one country to another is not controversial hence reports from many researchers have emphasized that minerals can be highly indicative of the geographical origin of honey and can be used as environmental indicators (Przyblowski and Wilcynska, 2001).

Honey bees may continuously be exposed to contaminants presents in the surrounding area for the duration of their foraging activity (Conti and Botre 2001), therefore honey bees and their products can be considered representative bio-indicators of the environmental pollution (conti and Botre 2001, Bogdanov et al 2007) emphasized that minerals produced from honey are originated from both natural sources (soil and plants) and anthropogenic origin the percentage mineral content is considered as a quality criterion indicating the possible botanical origin of honey (Vahanen et al 2001) the results obtained in the study (Agunibiade et al 2012) reported that there is wide variation in the mineral composition of honey obtained.

According to International Standard the average values of mineral contents of light and dark honey are potassium (205-1676mg/100), magnesium (1.9$3.5 \mathrm{mg} / 100)$, calcium $(4.9-5.1 \mathrm{mg} / 100)$, iron (2.4$9.4 \mathrm{mg} / 100)$ and zinc $(0.2-22.9 \mathrm{mg} / 100)$. The result shows that potassium and zinc in both samples agrees with the average value given in the mineral element. While magnesium and iron does not agree with the required standard. According to (Bertonceji et al 2007), White and Doner (1980), the average iron content $0.42 \mathrm{mg}$ were low in both honey samples and iron is an essential element for red blood production. Generally, the metals in honey samples were present in small amount this agrees with Crane (1990) who stated that most metals in honey are present in only 
minute amount called Trace elements. Zinc is one of them. Potassium is a mineral that helps the kidney job normally. It is crucial and plays important role in skeletal and smooth muscle curtailment. Calcium is the major abundant mineral in the body that is essential for strong bones and teeth. According to Amri and ladjama (2013) colour is usually an indication of flavour concentration, a lighter colour will indicate a milder flavour. Darker honey were also reported to have higher $\mathrm{pH}$, phytochemicals, antioxidant activities, mineral content but lower amount of sugars than lighter honey (Adebeyi et al 2004, Escuredo et al 2011, Eleazu et al 2013). The texture of honey is a function of the viscosity. The viscosity of honey is affected greatly by temperature and water content and to a lesser content by the composition of the honey (Durrani et al 2011).

Conclusion: The study reveals that honey from Forestry arboretum contain higher Calcium, magnesium and potassium which possess some nutritional and Medicinal quality that can be used as supplement for the need of human. However, the difference in composition and sensory quality of the honey samples may also be influenced by factors such as geographical and botanical origin of the flora, type and activity of the bee, the extraction technique and the storage conditions.

\section{REFERENCES}

Association of official Analytical chemist (AOAC) (2005). Method of analysis $18^{\text {th }}$ ed Association of official analysis chemist Inc Arlington pp.10251034.

Amril, A, and Ladjamya A, (2013). Physiochemical characterization of some multi floral honeys from honey bees Apis mellifera collected in the Algerian North east. Afr. J. Food Sci. 7(7): 108-173.

Adebiyi F.M. Akpan J, Obianjuwa EL, Olaniyi, H .B (2007). Chemical/physical Characterization of Nigerian Honey. Pak. J. Nutri. 3:278-281.

Agunbiade, S.O. Arojoyoye, O.A and Alao O.O (2012). Evaluation of some biochemical microbiological and organoleptic characteristics of some honey samples in Nigeria. Academia Arena 4(8): 41-45

Bogdanov,M, Haldimann,W;Luginbull \& P.Gallmann(2007). 'Minerals in honey; Environmental geographical and botanical aspects J. Apicultural Res. 46.90, 4; 269275
Bratul, BC (2005). Chemical contamination of bee honey identifying sensor of the environment pollution. J Cent Eur Agric, 6:95-8 (Google scholar).

Cantarelli, M .A, Pellarano R .G, Marchevsky E.J, Camina (2008). Quality of honey from Argentina: study of chemical composition and trace elements. The J. Argentine Chem. Soc. 96: 33-41

Codex Alimentarius (2001). Codex standard for honey, FAO, Rome. Alinorm, 1:19-26

Crane (1990). Bees and Beekeeping Science, ractice and world resources Heinemann Newness Oxford Uk.pp.614.

Conti, N.E. Botre (2001). Study of Chemical Composition and trace elements. J. Argentina Chem. Soc. 96:31-41.

Downey, G G, Hussey, K Kelly, D.J, Walshe, T.P \& Martin, P.G (2005). Preliminary contributed to the characterization of artisanal honey produced on the Island of Ireland by palymological and physiochemical data. Food Chem. 91:347-354.

Durrani, A, Srivastava, P and Verma S. (2011). Development and quality of honey based carrot candy...J. Food Sci. Technol: 48(4):502-505.

Escuredo, O, Seiyo,M and Ferhanded-Gonzalez, M. (2011). Descriptive analysis of rubus Honey from the north-west of spain. Inter. J. Food Sci. Technol. 46:2329-2336

Eleazu, C.O, Iroaganachi, M, and Okoronkwo .J. (2013). Determination of the physiochemical composition, microbial quality and free radical seavenging activities of some commercially sold honey samples in Aba, Nigeria. The effect of varying colors. J. Nutri. Food Sea 3 (2): 189.

Garcia M, C. Perez A.C \& Harrana A. (2001). Pollen analysis and antibacterial activity for Spanish honeys. Food Sci. Tech. Int. 7:155-158.

Hernandez, Fernandez-Torres, Garcia (2008). multivariase correlation between color and mineral composition of honeys and their botanical origin. $J$ Agric food chem. 53 (7): 2574-2580.

Iwe, M.O (2010). Handbook of Sensory methods and analysis. Rojoint communication services Ltd, Enugu, pp. 75-78. 
Nnadi,P.C and Anyanwu,D.I (2018): Effects of Extraction Method, soil Media on germination and Seedling Establishment of Chrysopyllum albidum. Inter. J. Horticulture. Forestry Res. 2 (1)1-11

Nnadi, J., Azonwu, O, and Nnadi, PC (2011): Evaluation of Point Care Testing and glucose Oxidase Assay. J. Pharm. Res. Clinical Practice $1(3), 38-48$

Przybylowski, P and Wilczynska A. (2001). Honey as an environmental marker. Food chem.. 74:289293.
Vanhanen, L .P, Emmertz, A, savage (2011) mineral analysis of monofloral New Zealand honey: Food Chem. 128 (1) 236-240

Vikas, N, Sakar, B.C, Sharma, H.K, Bahla, A.S (2003). Physcio-chemical properties and estimation of mineral contents in honey produced from plants in Northern India. J. Composite. Anal. $16(5) ; 613-619$ 